\title{
Gompertz and Logistic models for morphological traits of sudangrass cultivars during sowing seasons
}

\section{Modelos Gompertz e Logístico para caracteres morfológicos de cultivares de capim-sudão em épocas de semeadura}

\author{
Rafael Vieira Pezzini ${ }^{1}$; Alberto Cargnelutti Filho²*; Cláudia Marques de Bem³ \\ Jéssica Maronez de Souza ${ }^{4}$; Gabriela Görgen Chaves ${ }^{1}$; Ismael Mario Marcio Neu${ }^{4}$; \\ Andréia Procedi ${ }^{5}$
}

\begin{abstract}
The use of mathematical models in the study plant growth allows the identification of phases important to the cultivars and comparison between cultivars of the same species. The objectives of this work were to fit the Gompertz and Logistic growth models for the traits of plant height and stem length as a function of the accumulated thermal sum and accumulated solar radiation, to compare the fittings and the behavior of the sudangrass cultivars and indicate the model that best describes the growth of the cultivars during four sowing seasons. Were conducted eight uniformity trials with sudangrass. At 15 days after emergence, were began the collect and evaluation of five plants from each trial. Were measured plant height and stem length. The models were fitted using the values obtained for the traits of the five plants in each evaluation as a function of the accumulated thermal sum and accumulated solar radiation. Were estimated the parameters, determined their interval of confidence, critical points in the growth curves and quality indicators of the fit. The intrinsic nonlinearities and the parameter effect were also quantified. The accumulated thermal sum and accumulated solar radiation are adequate for the use as an independent variable in the model fitted. Both models were adequate to describe the growth of the traits plant height and stem length of cultivars BRS Estribo and CG Farrapo. However, the Logistic model is more accurate.
\end{abstract}

Key words: Nonlinear models. Cover crop. Sorghum sudanense (Piper) Stapf.

\section{Resumo}

A utilização de modelos matemáticos no estudo do crescimento de plantas possibilita a identificação de fases importantes para a cultura e a comparação entre cultivares de uma mesma espécie. Os objetivos deste trabalho foram ajustar modelos de crescimento, Gompertz e Logístico, para os caracteres altura de planta e comprimento de colmo em função da soma térmica acumulada e da radiação solar acumulada, comparar os ajustes e o comportamento das cultivares de capim-sudão e indicar o modelo que melhor descreve o crescimento das cultivares em quatro épocas de semeadura. Foram conduzidos oito ensaios

1 M.e, Programa de Pós-Graduação em Agronomia, Universidade Federal de Santa Maria, UFSM, Santa Maria, RS, Brasil. E-mail: rvpezzini@hotmail.com; gabrielachaves94@gmail.com

2 Prof. Dr., Departamento de Fitotecnia, UFSM, Santa Maria, RS, Brasil. E-mail: alberto.cargnelutti.filho@gmail.com

3 Pós-Doutoranda, Programa de Pós-Graduação em Agronomia, UFSM, Santa Maria, RS, Brasil. E-mail: claudia_debem@ hotmail.com

4 Discentes do Curso de Doutorado do Programa de Pós-Graduação em Agronomia, UFSM, Santa Maria, RS, Brasil. E-mail: jessica_maronez@hotmail.com; ismaelmmneu@hotmail.com

5 Discente do Curso de Graduação em Agronomia, UFSM, Santa Maria, RS, Brasil. E-mail: deiaprocedi123@gmail.com

* Author for correspondence

Received: Oct. 10, 2018 - Approved: July 15, 2019

Semina: Ciências Agrárias, Londrina, v. 40, n. 6, suplemento 3, p. 3399-3418, 2019 
de uniformidade com capim-sudão. Aos 15 dias após a emergência, foi iniciada a coleta e avaliação de cinco plantas de cada ensaio. Foram mensurados a altura de planta e o comprimento de colmo. O ajuste dos modelos foi realizado com os valores dos caracteres das cinco plantas em cada avaliação, em função da soma térmica acumulada e da radiação solar acumulada. Foram estimados os parâmetros, determinado o intervalo de confiança dos parâmetros, os pontos críticos das curvas de crescimento e os indicadores de qualidade do ajuste. Também foram quantificadas as não linearidades intrínseca e do efeito do parâmetro. A soma térmica acumulada e a radiação solar acumulada são adequadas para serem utilizadas como variável independente no ajuste dos modelos. Para descrever o crescimento dos caracteres altura de planta e comprimento de colmo das cultivares BRS Estribo e CG Farrapo ambos os modelos são adequados. Entretanto, o modelo Logístico apresenta maior precisão.

Palavras-chave: Modelos não lineares. Planta de cobertura. Sorghum sudanense (Piper) Stapf.

\section{Introduction}

The sudangrass (Sorghum sudanense (Piper) Stapf.), which belongs to the Poaceae family, is an annual species originated from southern Egypt and Sudan and cultivated in hot climates. Its purpose is to serve as fodder for animal feed and soil cover plant. The sudangrass is considered a rustic plant and is tolerant of acid soils, low fertility, and water deficit (SATTELL et al., 1998).

As it is a crop of which interest is fast growth, both for the supply of fodder and soil protection, the cultural treatments must be conducted according to the plant's needs and during the seasons in which it is most responsive. To do this, we must understand how the sudangrass grows, which can be accomplished by adjusting mathematical models.

These models are used to predict the occurrence of a specific phenomenon in many fields of study. In the agronomic field, the modeling has been used to estimate the period of occurrence of phenological phases (LEE et al., 2003), in the identification of intrinsic characteristics of the physiology of each species, in the form in which each organ contributes to the final growth (BENINCASA, 2003), as well as to predict crop yield (GOMES et al., 2014). Furthermore, the modeling allows to study the growth processes, relating them to the number of days since the cultivation or plant emergence (AUGOSTINHO et al., 2008), or even relating them to the meteorological variables of the environment in which the plant is found (OLIVEIRA et al., 2017). However, for these models to be reliable, it is necessary that, when fitted, they describe the phenomenon as close as possible to reality (BRITO et al., 2007).

Models can be linear or nonlinear. The nonlinear models are the most indicated to describe the growth curves of living organisms, given that, when welladjusted, they can present a smaller number of parameters when compared to the linear models and, also presenting parameters of biological interpretation (ARCHONTOULIS; MIGUEZ, 2015).

The nonlinear models most often used to represent plant growth are the Gompertz and Logistic models since they present sigmoidal curves. Both models were used to describe the growth of morphological traits of sunn hemp (BEM et al., 2017), of cashew fruits (MUIANGA et al., 2016), and of coffee fruits (FERNANDES et al., 2014).

Thus, the objectives of this work were to fit the Gompertz and Logistic growth models to the traits of plant height and stem length as a function of the accumulated thermal sum and accumulated solar radiation, compare the fittings and the behavior of the sudangrass cultivars and indicate the model that best describes the growth during four sowing seasons.

\section{Material and Methods}

Eight uniformity trials (blank experiments) with sudangrass [Sorghum sudanense (Piper) Stapf.] were conducted in the experimental area of the Department of Plant Science of the Federal University of Santa Maria (29 $42^{\prime}$ S, $53^{\circ} 49^{\prime} \mathrm{W}$ and 
$95 \mathrm{~m}$ altitude) in the agricultural year of 2016/2017. The region presents a Cfa subtropical climate, with hot summers and no defined dry season (ALVARES et al., 2013), with a soil classified as a Sandy Dystrophic Red Argisol (SANTOS et al., 2013).

The trials were composed by the combination of two cultivars (BRS Estribo and CG Farrapo), sown during four seasons (December 20 $0^{\text {th }}, 2016$, January $20^{\text {th }}, 2017$, February $7^{\text {th }}, 2017$ and February $\left.24^{\text {th }}, 2017\right)$. The cultural practices were performed homogeneously in all uniformity trials.

The area was prepared for sowing with light harrowing and the application of base fertilization in the dose of $33 \mathrm{~kg} \mathrm{ha}^{-1}$ of $\mathrm{N}, 132 \mathrm{~kg} \mathrm{ha}^{-1}$ of $\mathrm{P}_{2} \mathrm{O}_{5}$, and $132 \mathrm{~kg} \mathrm{ha}^{-1}$ of $\mathrm{K}_{2} \mathrm{O}\left(660 \mathrm{~kg} \mathrm{ha}^{-1}\right.$ of the commercial formula 5-20-20). Sowing was performed in rows spaced $0.4 \mathrm{~m}$, using a density of $25 \mathrm{~kg} \mathrm{ha}^{-1}$ of viable seeds for both cultivars. All sowing was done within the recommended season for cultivation in Rio Grande do Sul, from October to February (SILVEIRA et al., 2015). Each uniformity trial occupied an area of $9 \mathrm{~m} \times 16 \mathrm{~m}\left(144 \mathrm{~m}^{2}\right)$. When the plants presented three to four leaves, was applied nitrogen fertilization using $67.5 \mathrm{~kg} \mathrm{ha}^{-1}$ of $\mathrm{N}$ (150 $\mathrm{kg} \mathrm{ha}^{-1}$ of urea).

Plant collects and evaluations were performed three times a week, from 15 days after plant emergence until the end of the flowering stage. Were randomly collected five plants from each trial for each evaluation and measured plant height $(\mathrm{PH}$, in $\mathrm{cm}$ ), distance from the soil surface to the insertion of the last expanded leaf of the main stem, and stem length (SL, in $\mathrm{cm}$ ). To determine the SL, the leaves were removed from the plant and was measured the distance from the soil surface to the growing point.

In the period between the first sowing season (December $20^{\text {th }}, 2016$ ) and the last evaluation of the fourth sowing season (May 29 ${ }^{\text {th }}, 2017$ ), were collected the records of maximum and minimum air temperature, in ${ }^{\circ} \mathrm{C}$, and incident global solar radiation, in $\mathrm{MJ} \mathrm{m}^{-2}$ from the INMET Automatic Weather Station, located $30 \mathrm{~m}$ from the experimental area. With the data of temperature was calculated the daily thermal sum by the method proposed by Arnold (1960) according to the equation:

$$
S T d=(T \max +T \min ) / 2-T b
$$

Where STd is the daily thermal sum, Tmax is the maximum daily temperature, Tmin is the minimum daily temperature, and $\mathrm{Tb}$ is the inferior base temperature of the saccharine sorghum BRS 511 of $10.8^{\circ} \mathrm{C}$ (BANDEIRA et al., 2016) used as a reference, because were not found studies on the base temperature of the sudangrass and the saccharine sorghum is from the same genre as the sudangrass. Subsequently, were calculated the accumulated thermal sum (ATS) by summing the STd of the period between the plant emergence and the end of the evaluations of each cultivar in each season. To obtain the accumulated solar radiation (ASR) was adopted the same process, summing the daily incident global solar radiation data from the same period.

To fit the Gompertz and Logistic models, to each trait, were used the values of the five plants of each evaluation in function of the accumulated thermal sum (ATS) and accumulated solar radiation (ASR). The equation used in the Gompertz model was: $y_{i}=a \exp [-\exp (b-c x)]$, and the Logistic equation was: $y_{i}=a /[1+\exp (-b-c x)]$, where $y_{i}$ represents i-th observation of the dependent variable where $i=1$, $2, \ldots, \mathrm{n} ; a$ is the asymptotic value or final growth value; $b$ is the curve allocation parameter, having no biological interpretation but fundamental to the sigmoidal shape of the curve; $c$ is the maximum relative growth rate or precocity index; and $x$ is the independent variable. The initial estimates of the parameters were performed using the ordinary least square method.

After the fit, were applied the Shapiro-Wilk, Bartlett, and Durbin-Watson tests to verify the assumptions of normality, homoscedasticity, and residue independence, respectively. In the cases where the assumptions were not met, were 
performed data transformations with the Box-Cox transformation using the Action software.

Were calculated the critical points of the function of each model from which inferences can be made regarding the growth of the culture. Were calculate the inflection point (IP), maximum acceleration point (MAP), maximum deceleration point (MDP), and the asymptotic deceleration point (ADP) according to the equations described by Mischan and Pinho (2014).

The comparison between the growth models, fitted for the traits of the plant height and stem length, was carried out by overlapping the confidence intervals of the parameter estimates of each model. To do this, were calculated the lower and upper limits of the $95 \%$ confidence interval. According to the criterion, when at least one parameter estimate of a trait for a given season was contained in the confidence interval of the parameter of the same trait of another season, they do not differ. However, if none of the estimates were contained in the confidence interval of the other, the estimates of the parameters differ. These comparisons were conducted, first, between the cultivars within each sowing season and, later, between sowing seasons of each cultivar for each model.

The evaluation of the adjustment quality of the models was performed based on the adjusted coefficient of determination ( $\mathrm{R}^{2} \mathrm{aj}$ ), with the best adjustment presenting the highest value for $\mathrm{R}^{2} \mathrm{aj}$; Akaike's information criterion (AIC), where the best model presents the lowest AIC value; and residual standard deviation (RSD), where the best adjustment presents the lowest RSD value.

The behavior of the nonlinear models was analyzed using the nonlinearity measures of Bates and Watts curves (1988), in which the nonlinearity is decomposed into intrinsic nonlinearity (IN) and nonlinearity of the parameter effect (PE) based on the geometric concept of curvature. Thus, the model to be chosen is the one with the lowest IN and PE values.
Statistical analyses were performed using statistical software R (R DEVELOPMENT CORE TEAM, 2018) and the Microsoft Office Excel ${ }^{\circledR}$ application.

\section{Results and Discussion}

After the fit the Gompertz and Logistic models, were verified by the tests of Shapiro-Wilk, Bartlett, and Durbin-Watson, the assumptions of normality, homoscedasticity, and residue independence, respectively. From the p-values of the tests used in the residue analysis of the models, were observed that the residues of the models fitted to plant height and stem length data of the sudangrass cultivars sown in four seasons, as a function of ATS and ASR, presented normal distribution, homogeneity, and independence, fulfilling all assumptions ( $\mathrm{p}$-value $>0.05$ ).

In the Table 1, the estimates of the parameters of the Gompertz and Logistic models of the PH and SL traits as a function of the accumulated thermal sum, as well as the comparison between the cultivars within each sowing season. For the comparison, the criterion of overlapping of confidence intervals was adopted, as well as a study conducted by Bem et al. (2017), in which the authors stated that the cultivars present the same growth behavior if parameters $a$, $b$, and $c$ are equal.

The sowing seasons determined different cultivar behaviors using the Gompertz model when considering the $\mathrm{PH}$ models as a function of the ATS. When verifying only the final growth value (parameter $a$ ), there was no difference between the cultivars at seasons 1,2 , and 4 , which can indicate that there was no difference in the final height of the plants for these cultivars. When using the Logistic model, we observed that the cultivars did not differ in seasons 1 and 3, and presented values similar to those of parameters $a, b$, and $c$, which means they had similar growth curves that can be used for both cultivars during these seasons. For parameter $c$, there was no difference between seasons 1, 2, and 3, indicating that, during these seasons, the precocity index (parameter $c$ ) did not differ between cultivars. 


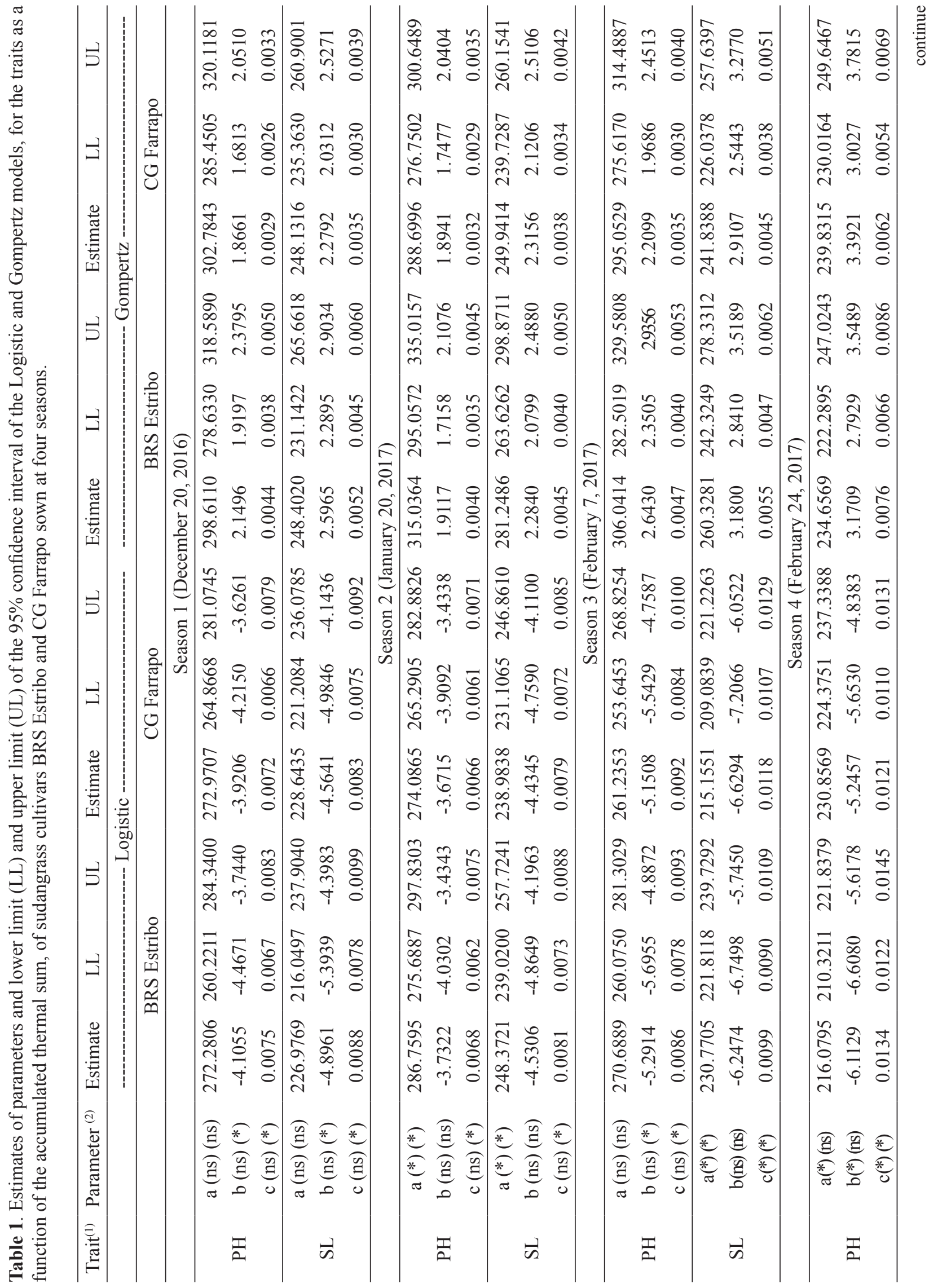




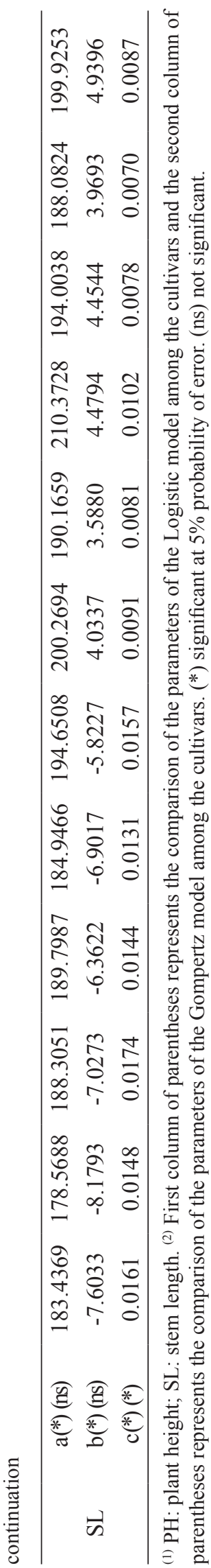

Concerning the SL trait, was verified a distinct behavior among cultivars during all sowing seasons when using the Gompertz model. However, there were no differences in the final growth value between the cultivars in seasons 1 and 4 . When using the Logistic model, was verified that the cultivars did not differ during season 1, presenting the same growth behavior. In the season 2 , the cultivars differed only by the value of $a$, not differing in the parameters $b$ and $c$. In the seasons when there were differences between the cultivars regarding $\mathrm{PH}$, was observed that during season 2, cultivar BRS Estribo showed plants with greater height and lower precocity index when compared to cultivar CG Farrapo. Contrary behavior was observed for season 4. At seasons in which differences between cultivars in the SL occurred, was verified that in the seasons 2 and 3, cultivar BRS Estribo presented higher values of stem length and lower precocity index when compared to cultivar CG Farrapo. In season 4, was verified a reduction of $\mathrm{SL}$ and $\mathrm{PH}$, as well as the inversion of cultivar behavior, indicating a stronger effect on cultivar BRS Estribo than on CG Farrapo by late sowing.

When the Gompertz and Logistic models were fitted as a function of ASR, were verified no differences between cultivars regarding $\mathrm{PH}$ at seasons 1 and 3 (Table 2). At the second sowing season, were observed that the cultivars did not differ for parameters $b$ and $c$, differing only in relation to plant height at the end of the development cycle. The cultivars presented the same behavior for SL at season 1 for Gompertz and Logistic models. As occurred in the models adjusted as a function of ATS, cultivar BRS Estribo presented higher values for $\mathrm{PH}$ and $\mathrm{SL}$ when compared to cultivar CG Farrapo at the seasons in which there were differences between cultivars apart from season 4 in which an inversion in behavior occurred. Martins Filho et al. (2008) reported differences between the cultivar behaviors in growth curves of common bean cultivars. 


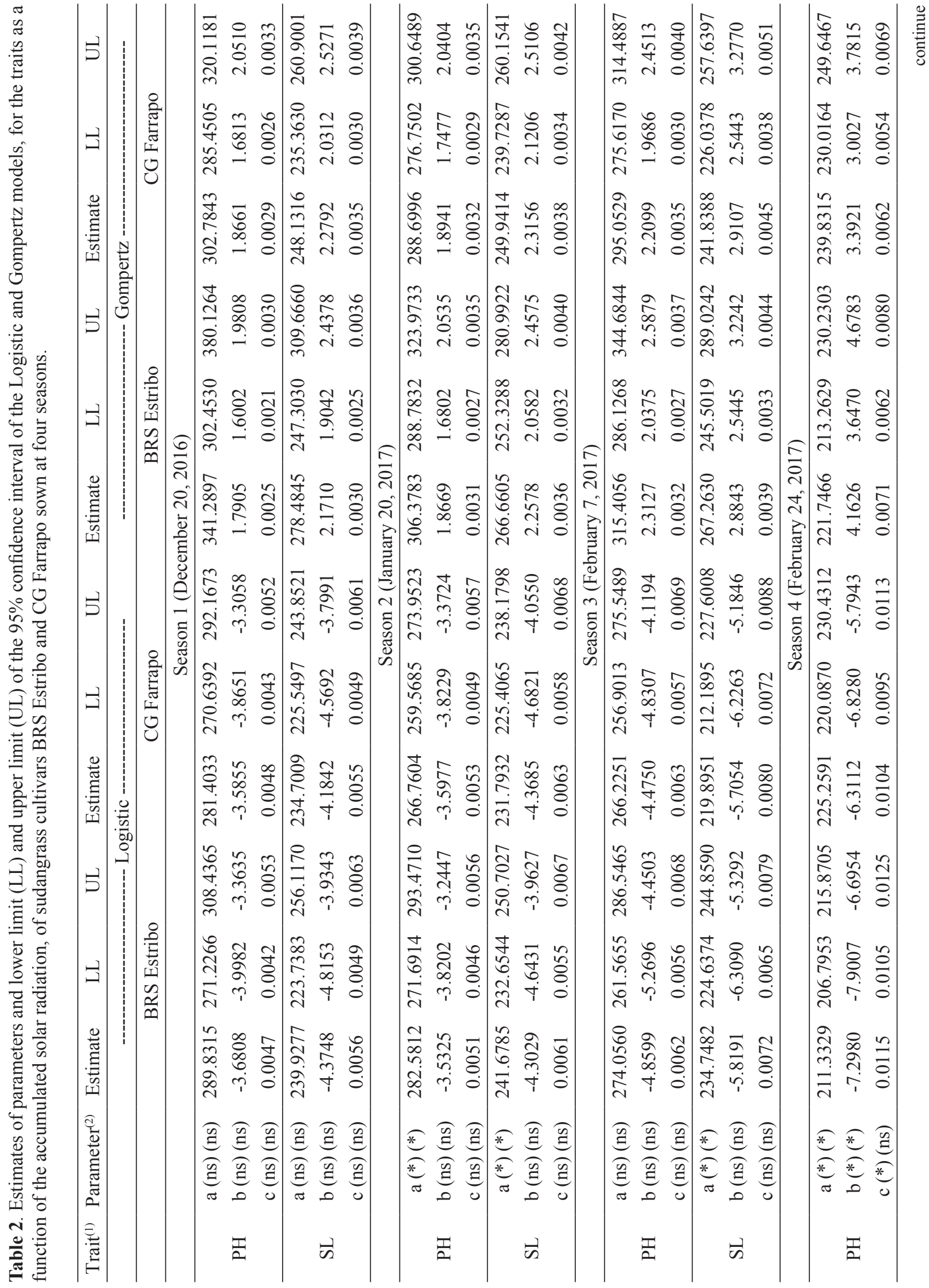




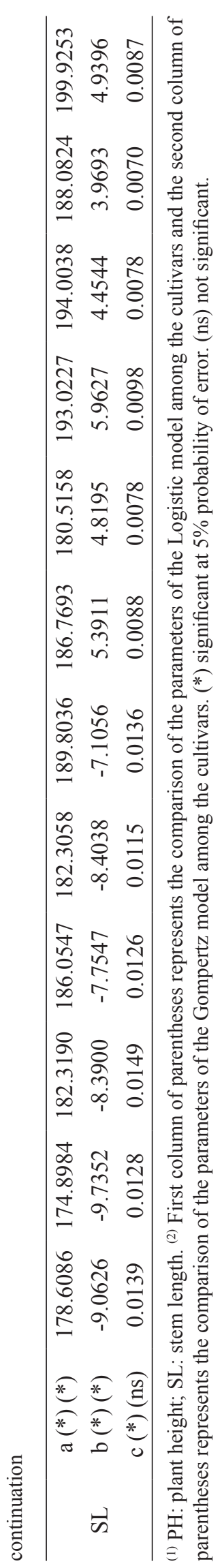

Were also compared the sowing seasons within each cultivar using both models (Table 3 ). When analyzing these comparisons based on the models fitted as a function of the ATS, was verified that, regarding the Logistic model, the PH did not differ between seasons 1 and 2 for cultivar CG Farrapo, while, with the Gompertz model, this behavior was observed for PH and SL traits. When was observed only the final growth value, it is possible to notice that seasons 1, 2, and 3 for both cultivars, evaluated using the Gompertz model, and seasons 1 and 3 of cultivar BRS Estribo and 1 and 2 of cultivar CG Farrapo, evaluated using the Logistic model, presented the same behavior between sowing seasons, resulting in plants with equal PH and SL. Season 4 presented distinct behavior from the other seasons, with smaller values for PH and SL. 
Table 3. Comparison of the parameters estimates, based on the overlapping of the confidence intervals of Logistic and Gompertz models, between sowing times of the sudangrass, cultivars BRS Estribo and CG Farrapo (December 20, 2016, January 20, 2017, February 7, 2017, and February 24, 2017).

\begin{tabular}{|c|c|c|c|c|c|c|c|c|c|}
\hline \multirow{3}{*}{ Season } & \multirow{3}{*}{ Season } & \multicolumn{4}{|c|}{------------- Logistic -------------- } & \multicolumn{4}{|c|}{-------------- Gompertz --------------- } \\
\hline & & \multicolumn{2}{|c|}{ BRS Estribo } & \multicolumn{2}{|c|}{ CG Farrapo } & \multicolumn{2}{|c|}{ BRS Estribo } & \multicolumn{2}{|c|}{ CG Farrapo } \\
\hline & & $\mathrm{PH}$ & SL & $\mathrm{PH}$ & SL & $\mathrm{PH}$ & SL & $\mathrm{PH}$ & SL \\
\hline \multicolumn{10}{|c|}{ As a function of accumulated thermal sum } \\
\hline & & \multicolumn{8}{|c|}{ Parameter $a$} \\
\hline 1 & 2 & $*$ & $*$ & $\mathrm{~ns}$ & $*$ & ns & $*$ & ns & ns \\
\hline 1 & 3 & ns & ns & $*$ & $*$ & ns & ns & $\mathrm{ns}$ & ns \\
\hline 1 & 4 & $*$ & $*$ & $*$ & $*$ & $*$ & $*$ & $*$ & $*$ \\
\hline 2 & 3 & $*$ & $*$ & $*$ & $*$ & ns & $*$ & ns & ns \\
\hline 2 & 4 & $*$ & $*$ & $*$ & $*$ & $*$ & $*$ & $*$ & $*$ \\
\hline 3 & 4 & $*$ & $*$ & $*$ & $*$ & $*$ & $*$ & $*$ & $*$ \\
\hline & & \multicolumn{8}{|c|}{ Parameter $b$} \\
\hline 1 & 2 & $*$ & $\mathrm{~ns}$ & ns & ns & $*$ & $*$ & $\mathrm{~ns}$ & $\mathrm{~ns}$ \\
\hline 1 & 3 & $*$ & $*$ & $*$ & $*$ & $*$ & $*$ & $*$ & $*$ \\
\hline 1 & 4 & $*$ & $*$ & $*$ & $*$ & $*$ & $*$ & $*$ & $*$ \\
\hline 2 & 3 & $*$ & $*$ & $*$ & $*$ & $*$ & $*$ & $*$ & $*$ \\
\hline 2 & 4 & $*$ & $*$ & $*$ & $*$ & $*$ & $*$ & $*$ & $*$ \\
\hline 3 & 4 & $*$ & $*$ & ns & ns & $*$ & $*$ & $*$ & $*$ \\
\hline & & \multicolumn{8}{|c|}{ Parameter $c$} \\
\hline 1 & 2 & $\mathrm{~ns}$ & ns & $\mathrm{ns}$ & ns & ns & $\mathrm{ns}$ & $\mathrm{ns}$ & ns \\
\hline 1 & 3 & $*$ & $\mathrm{~ns}$ & $*$ & $*$ & ns & $\mathrm{ns}$ & $*$ & $*$ \\
\hline 1 & 4 & $*$ & $*$ & $*$ & $*$ & $*$ & $*$ & $*$ & $*$ \\
\hline 2 & 3 & $*$ & $*$ & $*$ & $*$ & ns & $*$ & ns & ns \\
\hline 2 & 4 & $*$ & $*$ & $*$ & $*$ & $*$ & $*$ & $*$ & $*$ \\
\hline 3 & 4 & $*$ & $*$ & $*$ & $*$ & $*$ & $*$ & $*$ & $*$ \\
\hline
\end{tabular}

As a function of accumulated solar radiation

Parameter $a$

\begin{tabular}{|c|c|c|c|c|c|c|c|c|c|}
\hline 1 & 2 & ns & ns & $*$ & ns & ns & ns & ns & ns \\
\hline 1 & 3 & ns & ns & $*$ & $*$ & $\mathrm{~ns}$ & ns & $\mathrm{ns}$ & $\mathrm{ns}$ \\
\hline 1 & 4 & $*$ & $*$ & $*$ & $*$ & $*$ & $*$ & $*$ & * \\
\hline 2 & 3 & ns & $\mathrm{ns}$ & $\mathrm{ns}$ & $*$ & $\mathrm{~ns}$ & $\mathrm{~ns}$ & ns & ns \\
\hline 2 & 4 & $*$ & $*$ & $*$ & $*$ & $*$ & $*$ & $*$ & $*$ \\
\hline 3 & 4 & $*$ & $*$ & $*$ & $*$ & $*$ & $*$ & $*$ & $*$ \\
\hline & & \multicolumn{8}{|c|}{ Parameter $b$} \\
\hline 1 & 2 & ns & ns & ns & $\mathrm{ns}$ & ns & ns & ns & ns \\
\hline 1 & 3 & $*$ & $*$ & $*$ & $*$ & $*$ & $*$ & $*$ & $*$ \\
\hline 1 & 4 & $*$ & $*$ & $*$ & $*$ & $*$ & $*$ & $*$ & $*$ \\
\hline 2 & 3 & $*$ & $*$ & $*$ & $*$ & $*$ & $*$ & $*$ & $*$ \\
\hline 2 & 4 & $*$ & $*$ & $*$ & $*$ & $*$ & $*$ & $*$ & $*$ \\
\hline 3 & 4 & $*$ & $*$ & $*$ & $*$ & $*$ & $*$ & $*$ & $*$ \\
\hline
\end{tabular}


continuation

\begin{tabular}{|c|c|c|c|c|c|c|c|c|c|}
\hline \multirow[b]{2}{*}{1} & \multirow[b]{2}{*}{2} & \multicolumn{8}{|c|}{ Parameter $c$} \\
\hline & & ns & ns & $*$ & $*$ & $*$ & ns & ns & ns \\
\hline 1 & 3 & $*$ & $*$ & $*$ & $*$ & $*$ & $*$ & $*$ & $*$ \\
\hline 1 & 4 & $*$ & $*$ & $*$ & $*$ & $*$ & $*$ & $*$ & $*$ \\
\hline 2 & $3 \mathrm{t}$ & $*$ & $*$ & $*$ & $*$ & ns & $\mathrm{ns}$ & $\mathrm{ns}$ & $\mathrm{ns}$ \\
\hline 2 & 4 & $*$ & $*$ & $*$ & $*$ & $*$ & $*$ & $*$ & $*$ \\
\hline 3 & 4 & $*$ & $*$ & $*$ & $*$ & $*$ & $*$ & $*$ & $*$ \\
\hline
\end{tabular}

PH: plant height, in $\mathrm{cm}$; SL: stem length, in $\mathrm{cm} .\left(^{*}\right)$ significant at $5 \%$ probability of error. (ns) not significant.

When comparing the sowing seasons of each cultivar with the models fitted as a function of ASR, was verified that, by the Gompertz model, cultivar BRS Estribo presented the same behavior in seasons 1 and 2 for $\mathrm{PH}$, which also occurred for cultivar CG Farrapo in PH and SL. Parameters $a$ and $c$ did not differ between seasons 2 and 3 for PH and SL in both cultivars. By the Logistic model, cultivar BRS Estribo presented the same behavior in seasons 1 and 2 for PH and SL. The final growth of this cultivar did not differ between seasons 1, 2, and 3 for both traits. Cultivar CG Farrapo presented distinct behavior between seasons. However, there was no difference between parameters $a$ and $c$ of the PH for cultivar BRS Estribo in seasons 2 and 3 , and parameters $a$ and $b$ of SL in seasons 1 and 2. Therefore, when the adjustment was done in function of the ATS, season 4 presented the lowest values for PH and SL. Bem et al. (2017) found different behaviors between sowing seasons in the sunn hemp crop.
When observing the meteorological data of the season in which the tests were conducted (Figure 1), we observed that, over time, a drought period occurred, and the temperatures and global solar radiation incident reduced. These facts can explain the reduction in the values of PH and SL in season 4 since it was the one most affected by the changes in meteorological conditions. A reduction of plant development was observed in soybean (MELGES et al., 1989) and maize (MOZAMBANI; BICUDO, 2009) when submitted to smaller amounts of solar radiation and lower temperatures and light quantity, respectively. Thus, we can affirm that late sowing, even in the season preferred by the sudangrass, tends to reduce the crop cycle and, consequently, the growth of the plants, as indicated by Silveira et al. (2015). 
Figure 1. Daily minimum, maximum and average air temperatures, in ${ }^{\circ} \mathrm{C}$, precipitation, in mm, and incident global solar radiation, in $\mathrm{MJ} \mathrm{m}^{-2}$, corresponding to the period during which the trials with the cultivars of sudangrass, BRS Estribo and CG Farrapo were conducted. Data obtained at the INMET Automatic Weather Station of Federal University os Santa Maria (Source: INMET Network Data).
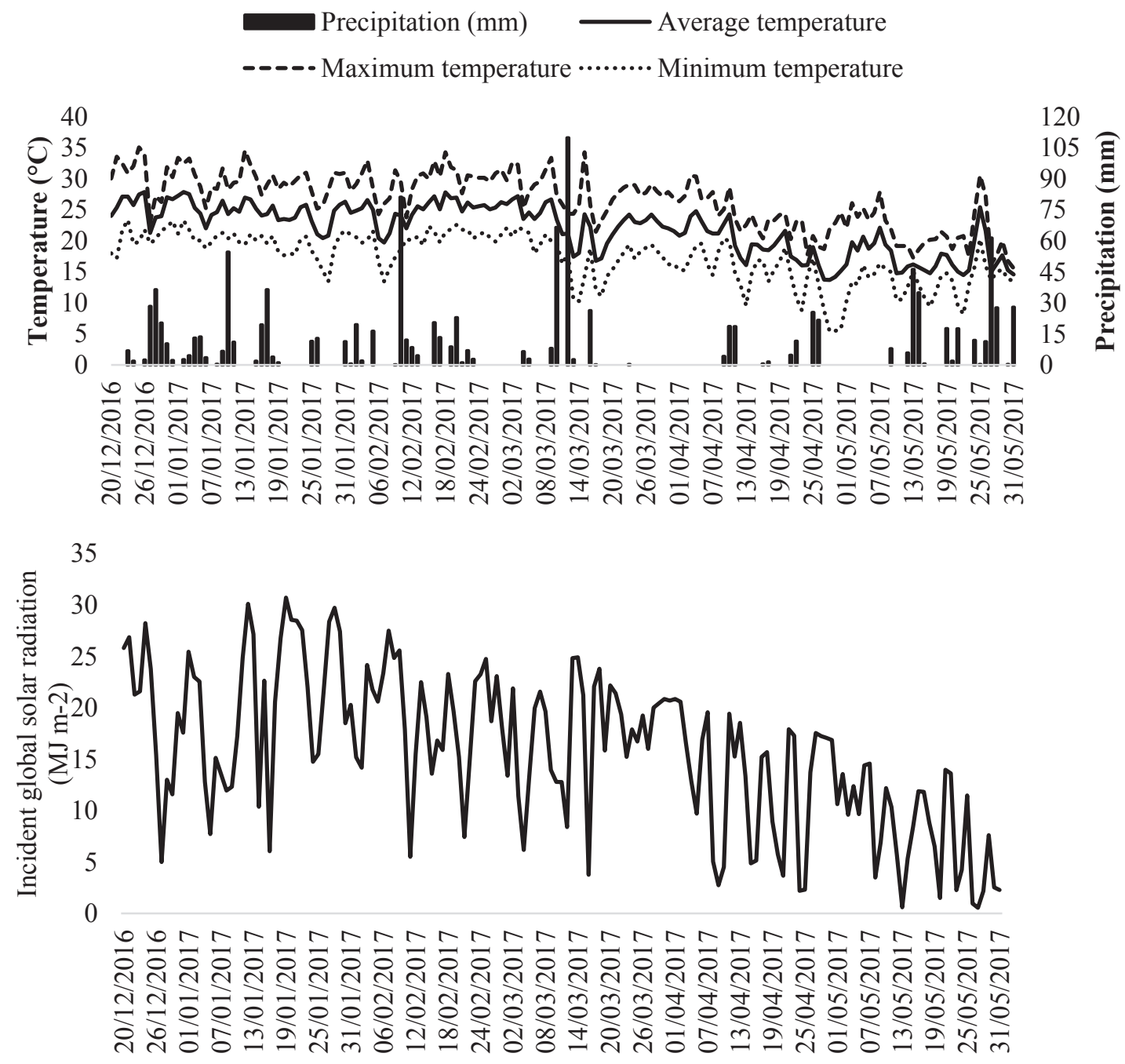

We indicated the models to describe the sudangrass growth using quality indicators, which evaluate the fit quality. For PH and SL in all models fitted according to the ATS, were observed that the values of the adjusted coefficient of determination $\left(\mathrm{R}^{2} \mathrm{aj}\right)$ were equal to or superior to 0.9524 , demonstrating the good capacity of the models in explaining the growth curves (Table 4). 
Table 4. Fit quality indicators, curvature nonlinearity measures and critical points of Logistic and Gompertz models fitted to the traits plant height $(\mathrm{PH})$ and stem length $(\mathrm{SL})$ as a function of accumulated thermal sum $\left({ }^{\circ} \mathrm{C}\right)$ for cultivars BRS Estribo and CG Farrapo in four sowing seasons.

\begin{tabular}{|c|c|c|c|c|c|c|c|c|c|}
\hline \multirow[t]{3}{*}{ Statistic $^{(1)}$} & & \multicolumn{4}{|c|}{ 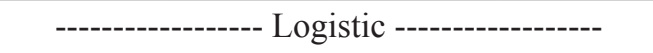 } & \multicolumn{4}{|c|}{------------------ Gompertz ------------------ } \\
\hline & & \multicolumn{2}{|c|}{ BRS Estribo } & \multicolumn{2}{|c|}{ CG Farrapo } & \multicolumn{2}{|c|}{ BRS Estribo } & \multicolumn{2}{|c|}{ CG Farrapo } \\
\hline & & $\mathrm{PH}$ & SL & $\mathrm{PH}$ & SL & $\mathrm{PH}$ & SL & $\mathrm{PH}$ & SL \\
\hline & & \multicolumn{8}{|c|}{ Season 1 (December 20, 2016) } \\
\hline $\mathrm{R}^{2} \mathrm{aj}$ & & 0.9572 & 0.9548 & 0.9653 & 0.9563 & 0.9576 & 0.9597 & 0.9637 & 0.9614 \\
\hline AIC & & 5.7675 & 5.6268 & 5.5754 & 5.6351 & 5.7587 & 5.5151 & 5.6200 & 5.5122 \\
\hline RSD & & 17.4066 & 16.2296 & 15.8469 & 16.3552 & 17.3269 & 15.3227 & 16.2045 & 15.3539 \\
\hline IN & & 0.0570 & 0.0662 & 0.0515 & 0.0657 & 0.0534 & 0.0733 & 0.0483 & 0.0665 \\
\hline $\mathrm{PE}$ & & 0.3529 & 0.3729 & 0.2151 & 0.2269 & 0.6604 & 0.6716 & 0.3374 & 0.3098 \\
\hline \multirow[t]{2}{*}{ IP } & $\mathrm{x}$ & 549.8603 & 553.3317 & 542.2487 & 548.1281 & 487.1498 & 498.6664 & 466.2146 & 478.9974 \\
\hline & $\mathrm{y}$ & 136.1403 & 113.4884 & 136.4853 & 114.3217 & 109.8529 & 91.3820 & 105.5146 & 87.5518 \\
\hline \multirow[t]{2}{*}{ MAP } & $\mathrm{x}$ & 373.4787 & 404.4964 & 360.1016 & 389.9677 & 269.0454 & 313.8278 & 258.5482 & 301.8465 \\
\hline & $\mathrm{y}$ & 57.5397 & 47.9659 & 57.6855 & 48.3180 & 21.7825 & 18.1200 & 20.9223 & 17.3605 \\
\hline \multirow[t]{2}{*}{ MDP } & $\mathrm{x}$ & 726.2420 & 702.1670 & 724.3959 & 706.2885 & 705.2541 & 683.5051 & 673.8809 & 656.1482 \\
\hline & $\mathrm{y}$ & 214.7409 & 179.0110 & 215.2852 & 180.3254 & 203.8075 & 169.5389 & 195.7587 & 162.4328 \\
\hline \multirow[t]{3}{*}{$\mathrm{ADP}$} & $\mathrm{x}$ & 856.8883 & 812.4096 & 859.3127 & 823.4383 & 894.4387 & 843.8349 & 854.0115 & 809.8095 \\
\hline & $\mathrm{y}$ & 247.2984 & 206.1514 & 247.9252 & 207.6650 & 252.9989 & 210.4592 & 243.0074 & 201.6379 \\
\hline & & \multicolumn{8}{|c|}{ Season 2 (January 20, 2017) } \\
\hline $\mathrm{R}^{2} \mathrm{aj}$ & & 0.9580 & 0.9723 & 0.9718 & 0.9711 & 0.9524 & 0.9730 & 0.9669 & 0.9680 \\
\hline AIC & & 5.7289 & 5.1733 & 5.2013 & 5.1453 & 5.8537 & 5.1501 & 5.3638 & 5.2454 \\
\hline RSD & & 17.1419 & 12.9679 & 13.1669 & 12.7931 & 18.2504 & 12.8097 & 14.2825 & 13.4483 \\
\hline IN & & 0.0496 & 0.0462 & 0.0380 & 0.0449 & 0.0491 & 0.0534 & 0.0373 & 0.0529 \\
\hline $\mathrm{PE}$ & & 0.3268 & 0.3185 & 0.2838 & 0.2764 & 0.6648 & 0.6800 & 0.6162 & 0.5911 \\
\hline \multirow[t]{2}{*}{ IP } & $\mathrm{x}$ & 548.5524 & 562.4343 & 555.1288 & 563.1636 & 479.0868 & 510.9289 & 485.1661 & 501.9311 \\
\hline & $\mathrm{y}$ & 143.3795 & 124.1860 & 137.0433 & 119.4919 & 115.8954 & 103.4656 & 111.5096 & 97.1485 \\
\hline \multirow[t]{2}{*}{ MAP } & $\mathrm{x}$ & 354.9892 & 398.9453 & 356.0050 & 395.9150 & 237.8972 & 295.6332 & 234.3906 & 287.6752 \\
\hline & $\mathrm{y}$ & 60.5994 & 52.4872 & 57.9213 & 50.5032 & 22.9807 & 20.5160 & 22.1110 & 19.2634 \\
\hline \multirow[t]{2}{*}{ MDP } & $\mathrm{x}$ & 742.1156 & 725.9234 & 754.2525 & 730.4123 & 720.2764 & 726.2245 & 735.9415 & 716.1870 \\
\hline & $\mathrm{y}$ & 226.1601 & 195.8849 & 216.1652 & 188.4806 & 215.0181 & 191.9573 & 206.8811 & 180.2373 \\
\hline \multirow[t]{3}{*}{ ADP } & $\mathrm{x}$ & 885.4883 & 847.0201 & 901.7439 & 854.2938 & 929.4852 & 912.9728 & 953.4651 & 902.0334 \\
\hline & $\mathrm{y}$ & 260.4488 & 225.5835 & 248.9386 & 217.0566 & 266.9153 & 238.2885 & 256.8144 & 223.7398 \\
\hline & & \multicolumn{8}{|c|}{ Season 3 (February 7, 2017) } \\
\hline $\mathrm{R}^{2} \mathrm{aj}$ & & 0.9657 & 0.9714 & 0.9667 & 0.9693 & 0.9542 & 0.9689 & 0.9553 & 0.9624 \\
\hline AIC & & 5.6432 & 5.3067 & 5.5620 & 5.3131 & 5.9280 & 5.3909 & 5.8550 & 5.5097 \\
\hline RSD & & 16.5047 & 13.9049 & 15.8413 & 13.9429 & 19.0601 & 14.5076 & 18.3702 & 15.4288 \\
\hline IN & & 0.0555 & 0.0591 & 0.0541 & 0.0623 & 0.0754 & 0.0778 & 0.0714 & 0.0860 \\
\hline PE & & 0.3416 & 0.3430 & 0.2599 & 0.2491 & 0.8442 & 0.7649 & 0.5623 & 0.5117 \\
\hline \multirow[t]{2}{*}{ IP } & $\mathrm{x}$ & 617.6527 & 628.2961 & 561.7786 & 561.6924 & 566.1190 & 583.3360 & 505.7207 & 514.8199 \\
\hline & $\mathrm{y}$ & 135.3440 & 115.3854 & 130.6177 & 107.5776 & 112.5863 & 95.7694 & 104.4589 & 84.6769 \\
\hline
\end{tabular}


continuation

\begin{tabular}{cccccccccc} 
MAP & $\mathrm{x}$ & 463.9260 & 495.8508 & 418.1432 & 450.1100 & 359.9745 & 406.7873 & 325.0802 & 377.5317 \\
& $\mathrm{y}$ & 57.2033 & 48.7676 & 55.2055 & 45.4676 & 22.3245 & 18.9899 & 20.7130 & 16.7904 \\
MDP & $\mathrm{x}$ & 771.3795 & 760.7415 & 705.4141 & 673.2748 & 772.2635 & 759.8847 & 686.3613 & 652.1081 \\
& $\mathrm{y}$ & 213.4856 & 182.0030 & 206.0298 & 169.6875 & 208.8788 & 177.6787 & 193.8002 & 157.0991 \\
ADP & $\mathrm{x}$ & 885.2452 & 858.8440 & 811.8052 & 755.9242 & 951.0741 & 913.0237 & 843.0496 & 771.1924 \\
& $\mathrm{y}$ & 245.8528 & 209.5969 & 237.2665 & 195.4143 & 259.2942 & 220.5636 & 240.5762 & 195.0169 \\
\hline & & \multicolumn{7}{c}{ Season 4 (February 24,2017$)$} \\
\hline R $2 \mathrm{aj}$ & & 0.9726 & 0.9832 & 0.9721 & 0.9737 & 0.9599 & 0.9769 & 0.9648 & 0.9708 \\
AIC & & 5.0606 & 4.4082 & 5.1379 & 4.8735 & 5.4386 & 4.7169 & 5.3674 & 4.9801 \\
RSD & & 12.3428 & 8.8425 & 12.7631 & 11.1790 & 14.9402 & 10.3541 & 14.3318 & 11.7922 \\
IN & & 0.0561 & 0.0565 & 0.0507 & 0.0604 & 0.0938 & 0.0872 & 0.0748 & 0.0848 \\
PE & & 0.2422 & 0.2346 & 0.2592 & 0.2306 & 0.5833 & 0.5453 & 0.5744 & 0.4364 \\
IP & $\mathrm{x}$ & 457.2238 & 473.5002 & 434.5329 & 442.5920 & 416.2010 & 440.8413 & 391.2437 & 402.2487 \\
& $\mathrm{y}$ & 108.0397 & 91.7186 & 115.4284 & 94.8994 & 86.3254 & 73.6750 & 92.6993 & 74.3932 \\
MAP & $\mathrm{x}$ & 358.7198 & 391.4857 & 325.4405 & 350.9767 & 289.8768 & 335.6579 & 252.5977 & 290.4329 \\
& $\mathrm{y}$ & 45.6630 & 38.7648 & 48.7858 & 40.1092 & 17.1173 & 14.6089 & 18.3812 & 14.7513 \\
MDP & $\mathrm{x}$ & 555.7278 & 555.5147 & 543.6253 & 534.2072 & 542.5253 & 546.0247 & 529.8898 & 514.0644 \\
& $\mathrm{y}$ & 170.4165 & 144.6722 & 182.0711 & 149.6895 & 160.1576 & 136.6875 & 171.9829 & 138.0201 \\
ADP & $\mathrm{x}$ & 628.6900 & 616.2630 & 624.4302 & 602.0669 & 652.0994 & 637.2612 & 650.1519 & 611.0538 \\
& $\mathrm{y}$ & 196.2539 & 166.6063 & 209.6754 & 172.3843 & 198.8136 & 169.6787 & 213.4931 & 171.3329 \\
\hline
\end{tabular}

${ }^{(1)} \mathrm{R}^{2}$ aj: adjusted coefficient of determination; AIC: Akaike's information criterion; RSD: residual standard deviation; IN: intrinsic nonlinearity; PE: parameter-effects nonlinearity; IP: inflection point; MAP: maximum acceleration point; MDP: maximum deceleration point; ADP: asymptotic deceleration point.

We also observed $\mathrm{R}^{2}$ aj values equal to or superior to 0.9415 at the models fitted according to the ASR (Table 5). Thus, we can infer that the Gompertz and Logistic models adjusted for the ASR can also be satisfactorily used to describe the growth curves for plant height and stem length of both cultivars of sudangrass sown in the four seasons, considering the ASR independent variable as an alternative to fit growth models in crops that have no defined base temperature or that do not respond to the thermal sum.

In some cases, when using the Gompertz model, the estimates of the asymptote were higher when compared to the estimates of the Logistic model. Although it did not overestimate the observed values, these superior values obtained for the parameter $a$ influenced the quality of the fit. When comparing the Gompertz with the Logistic models, considering all the quality indicators, we found higher values of $\mathrm{R}^{2} \mathrm{aj}$ and lower values of AIC and RSD for the Logistic model, indicating its superior adequacy to describe crop growth curves. These results are consistent with those found by Muianga et al. (2016) and Maia et al. (2009), who evaluated the quality of the fit of growth models, obtaining better performance from the Logistic model. In addition to the quality indicators, the nonlinearity measures of the Bates and Watts curves reinforce the choice of the Logistic model as preferred since, in most cases, it presents lower values for both intrinsic nonlinearity (IN) and nonlinearity of the parameter effect (PE). These measures indicate that this model behaves closer to linear, which is desired to better describe the growth curve of the sudangrass. 
Table 5. Fit quality indicators, curvature nonlinearity measures and critical points of Logistic and Gompertz models fitted to the traits plant height (PH) and stem length (SL) as a function of accumulated solar radiation $\left(\mathrm{MJ} \mathrm{m}^{-2}\right)$ for cultivars BRS Estribo and CG Farrapo in four sowing seasons.

\begin{tabular}{|c|c|c|c|c|c|c|c|c|c|}
\hline \multirow[t]{3}{*}{ Statistic $^{(1)}$} & & \multicolumn{4}{|c|}{---------------- Logistic ----------------- } & \multicolumn{4}{|c|}{------------------ Gompertz ------------------- } \\
\hline & & \multicolumn{2}{|c|}{ BRS Estribo } & \multicolumn{2}{|c|}{ CG Farrapo } & \multicolumn{2}{|c|}{ BRS Estribo } & \multicolumn{2}{|c|}{ CG Farrapo } \\
\hline & & $\mathrm{PH}$ & SL & $\mathrm{PH}$ & SL & $\mathrm{PH}$ & SL & $\mathrm{PH}$ & SL \\
\hline & & \multicolumn{8}{|c|}{ Season 1 (December 20, 2016) } \\
\hline $\mathrm{R}^{2} \mathrm{aj}$ & & 0.9551 & 0.9539 & 0.9605 & 0.9551 & 0.9541 & 0.9570 & 0.9557 & 0.9565 \\
\hline AIC & & 5.8166 & 5.3103 & 5.7045 & 5.6622 & 5.8377 & 5.5792 & 5.8182 & 5.6327 \\
\hline RSD & & 17.8366 & 16.3864 & 16.9010 & 16.5636 & 18.0258 & 15.8208 & 17.8947 & 16.3052 \\
\hline IN & & 0.0558 & 0.0678 & 0.0538 & 0.0661 & 0.0517 & 0.0783 & 0.0527 & 0.0755 \\
\hline PE & & 0.5923 & 0.6069 & 0.2983 & 0.2935 & 1.4115 & 1.3255 & 0.5402 & 0.4588 \\
\hline \multirow[t]{2}{*}{ IP } & $\mathrm{x}$ & 778.2011 & 778.5745 & 749.3934 & 756.6479 & 708.8905 & 713.3724 & 640.8308 & 655.2578 \\
\hline & $\mathrm{y}$ & 144.9157 & 119.9637 & 140.7016 & 117.3505 & 125.5535 & 102.4487 & 111.3881 & 91.2825 \\
\hline \multirow[t]{2}{*}{ MAP } & $\mathrm{x}$ & 499.7706 & 544.1969 & 474.1381 & 518.4938 & 327.8449 & 397.1239 & 310.3363 & 378.5615 \\
\hline & $\mathrm{y}$ & 61.2486 & 50.7027 & 59.4675 & 49.5981 & 24.8958 & 20.3144 & 22.0869 & 18.1002 \\
\hline \multirow[t]{2}{*}{ MDP } & $\mathrm{x}$ & 1056.6317 & 1012.9522 & 1024.6487 & 994.8020 & 1089.9361 & 1029.6209 & 971.3254 & 931.9541 \\
\hline & $\mathrm{y}$ & 228.5829 & 189.2250 & 221.9358 & 185.1028 & 232.9364 & 190.0707 & 206.6558 & 169.3543 \\
\hline \multirow[t]{3}{*}{ ADP } & $\mathrm{x}$ & 1262.8658 & 1186.5563 & 1228.5309 & 1171.2032 & 1420.4565 & 1303.9360 & 1257.9977 & 1171.9616 \\
\hline & $\mathrm{y}$ & 263.2390 & 217.9139 & 255.5841 & 213.1667 & 289.1584 & 235.9466 & 256.5347 & 210.2300 \\
\hline & & \multicolumn{8}{|c|}{ Season 2 (January 20, 2017) } \\
\hline $\mathrm{R}^{2} \mathrm{aj}$ & & 0.9572 & 0.9682 & 0.9751 & 0.9731 & 0.9569 & 0.9738 & 0.9742 & 0.9740 \\
\hline AIC & & 5.7478 & 5.3103 & 5.0779 & 5.0715 & 5.7557 & 5.1218 & 5.1159 & 5.0380 \\
\hline RSD & & 17.3060 & 13.9052 & 12.3800 & 12.3383 & 17.3728 & 12.6332 & 12.6166 & 12.1241 \\
\hline IN & & 0.0510 & 0.0480 & 0.0364 & 0.0437 & 0.0442 & 0.0466 & 0.0318 & 0.0436 \\
\hline PE & & 0.3529 & 0.3294 & 0.2456 & 0.2330 & 0.6260 & 0.5802 & 0.4502 & 0.4140 \\
\hline \multirow[t]{2}{*}{ IP } & $\mathrm{x}$ & 691.8041 & 703.5239 & 682.5781 & 690.2852 & 597.9030 & 629.4565 & 590.1847 & 609.4036 \\
\hline & $\mathrm{y}$ & 141.2905 & 120.8393 & 133.3802 & 115.8966 & 112.7103 & 98.0989 & 106.2066 & 91.9483 \\
\hline \multirow[t]{2}{*}{ MAP } & $\mathrm{x}$ & 433.8900 & 488.2000 & 432.7138 & 482.1878 & 289.6647 & 361.1440 & 290.2987 & 356.1197 \\
\hline & $\mathrm{y}$ & 59.7164 & 51.0727 & 56.3731 & 48.9837 & 22.3491 & 19.4519 & 21.0595 & 18.2323 \\
\hline \multirow[t]{2}{*}{ MDP } & $\mathrm{x}$ & 949.7181 & 918.8478 & 932.4423 & 898.3825 & 906.1413 & 897.7691 & 890.0707 & 862.6875 \\
\hline & $\mathrm{y}$ & 222.8648 & 190.6058 & 210.3873 & 182.8095 & 209.1088 & 182.0007 & 197.0427 & 170.5896 \\
\hline \multirow[t]{3}{*}{$\mathrm{ADP}$} & $\mathrm{x}$ & 1140.7556 & 1078.3387 & 1117.5173 & 1052.5207 & 1173.5084 & 1130.5044 & 1150.1930 & 1082.3869 \\
\hline & $\mathrm{y}$ & 256.6539 & 219.5041 & 242.2847 & 210.5257 & 259.5797 & 225.9287 & 244.6014 & 211.7634 \\
\hline & & \multicolumn{8}{|c|}{ Season 3 (February 7, 2017) } \\
\hline $\mathrm{R}^{2} \mathrm{aj}$ & & 0.9565 & 0.9682 & 0.9606 & 0.9656 & 0.9415 & 0.9618 & 0.9471 & 0.9565 \\
\hline AIC & & 5.8772 & 5.4148 & 5.7306 & 5.4246 & 6.1726 & 5.5940 & 6.0259 & 5.6558 \\
\hline RSD & & 18.5832 & 14.6758 & 17.2416 & 14.7512 & 21.5416 & 16.0828 & 19.9861 & 16.5999 \\
\hline IN & & 0.0612 & 0.0645 & 0.0566 & 0.0677 & 0.0832 & 0.0977 & 0.0670 & 0.1016 \\
\hline $\mathrm{PE}$ & & 0.3766 & 0.3632 & 0.3079 & 0.3255 & 1.0010 & 0.8905 & 0.6992 & 0.7280 \\
\hline \multirow[t]{2}{*}{ IP } & $\mathrm{x}$ & 786.4155 & 804.3783 & 712.2588 & 715.5958 & 717.7906 & 743.4584 & 632.8089 & 650.8210 \\
\hline & $\mathrm{y}$ & 137.0283 & 117.3743 & 133.1128 & 109.9476 & 116.0312 & 98.3206 & 108.5439 & 88.9675 \\
\hline
\end{tabular}




\begin{tabular}{|c|c|c|c|c|c|c|c|c|c|}
\hline \multirow[t]{2}{*}{ MAP } & $\mathrm{x}$ & 573.3104 & 622.3348 & 502.6477 & 550.4181 & 419.0781 & 495.3876 & 357.2198 & 435.6233 \\
\hline & $\mathrm{y}$ & 57.9148 & 49.6081 & 56.2600 & 46.4693 & 23.0076 & 19.4958 & 21.5230 & 17.6412 \\
\hline \multirow[t]{2}{*}{ MDP } & $\mathrm{x}$ & 999.5206 & 986.4219 & 921.8698 & 880.7735 & 1016.5032 & 991.5292 & 908.3980 & 866.0187 \\
\hline & $\mathrm{y}$ & 216.1411 & 185.1400 & 209.9651 & 173.4258 & 215.2701 & 182.4119 & 201.3790 & 165.0594 \\
\hline \multirow[t]{3}{*}{ ADP } & $\mathrm{x}$ & 1157.3680 & 1121.2619 & 1077.1292 & 1003.1210 & 1275.6076 & 1206.7067 & 1147.4451 & 1052.6820 \\
\hline & $\mathrm{y}$ & 248.9109 & 213.2096 & 241.7985 & 199.7194 & 267.2281 & 226.4392 & 249.9842 & 204.8984 \\
\hline & & \multicolumn{8}{|c|}{ Season 4 (February 24, 2017) } \\
\hline $\mathrm{R}^{2} \mathrm{aj}$ & & 0.9740 & 0.9840 & 0.9721 & 0.9769 & 0.9599 & 0.9781 & 0.9612 & 0.9718 \\
\hline AIC & & 5.0019 & 4.3544 & 5.1350 & 4.7436 & 5.4215 & 4.6549 & 5.4603 & 4.9421 \\
\hline RSD & & 12.0338 & 8.6112 & 12.7689 & 10.4736 & 14.9398 & 10.0782 & 15.0624 & 11.5891 \\
\hline IN & & 0.0587 & 0.0542 & 0.0550 & 0.0609 & 0.0992 & 0.0843 & 0.0935 & 0.0879 \\
\hline PE & & 0.1803 & 0.1613 & 0.1934 & 0.1671 & 0.3942 & 0.3214 & 0.4195 & 0.3039 \\
\hline \multirow[t]{2}{*}{ IP } & $\mathrm{x}$ & 635.7831 & 653.5988 & 606.4307 & 617.7802 & 585.7482 & 612.8892 & 551.2367 & 569.7745 \\
\hline & $\mathrm{y}$ & 105.6664 & 89.3044 & 112.6295 & 93.0273 & 81.5760 & 68.7086 & 88.2291 & 71.3700 \\
\hline \multirow[t]{2}{*}{ MAP } & $\mathrm{x}$ & 521.0534 & 558.6196 & 479.8863 & 512.8645 & 450.3203 & 503.4758 & 394.8378 & 446.6693 \\
\hline & $\mathrm{y}$ & 44.6599 & 37.7444 & 47.6029 & 39.3180 & 16.1756 & 13.6241 & 17.4948 & 14.1518 \\
\hline \multirow[t]{2}{*}{ MDP } & $\mathrm{x}$ & 750.5127 & 748.5779 & 732.9751 & 722.6959 & 721.1761 & 722.3026 & 707.6355 & 692.8796 \\
\hline & $\mathrm{y}$ & 166.6730 & 140.8642 & 177.6563 & 146.7367 & 151.3461 & 127.4734 & 163.6894 & 132.4112 \\
\hline \multirow[t]{2}{*}{ ADP } & $\mathrm{x}$ & 835.4932 & 818.9292 & 826.7069 & 800.4072 & 838.6468 & 817.2082 & 843.2965 & 799.6615 \\
\hline & $\mathrm{y}$ & 191.9427 & 162.2210 & 204.5912 & 168.9839 & 187.8753 & 158.2407 & 203.1978 & 164.3702 \\
\hline
\end{tabular}

(1) $\mathrm{R}^{2}$ aj: adjusted coefficient of determination; AIC: Akaike's information criterion; RSD: residual standard deviation; IN: intrinsic nonlinearity; PE: parameter-effects nonlinearity; IP: inflection point; MAP: maximum acceleration point; MDP: maximum deceleration point; ADP: asymptotic deceleration point.

The growth curves of each model present critical points with specific meanings from which it is possible to infer about the growth of the crop, establishing important periods for managing the crop cycle. In Tables 4 and 5, we present the inflection point (IP), maximum acceleration point (MAP), maximum deceleration point (MDP), and asymptotic deceleration point (ADP) values.

When comparing the models, we noticed that by the Gompertz model, the need for ATS or ASR is smaller to reach the MAP and IP when compared to the Logistic model and that the plants reach MAP and IP with lower PH and SL in the Gompertz model. Figures 2 and 3 show the growth curves and Logistic equations that are most indicated, with their respective critical points. Notice that cultivar
CG Farrapo demands a lower accumulated thermal sum or accumulated solar radiation to reach MAP and IP when compared to cultivar BRS Estribo. The period between MAP and IP is important, given that it is during this phase that the plant growth rate increases until reaching a maximum rate, that is, it is in this period that the plant presents a rapid increase in height and stem length, requiring more nutrients. Thus, the prediction of the occurrence in this period is important since it is where the plant requires more attention, being more responsive to fertilization and control of invasive plants. Therefore, we can infer that fertilizing management and weed control should be performed earlier in the CG Farrapo cultivar when compared to BRS Estribo. 
Figure 2. Graphs of the Logistic models for the plant height $(\mathrm{PH}$, in $\mathrm{cm})$ as a function of accumulated thermal sum (ATS, in ${ }^{\circ} \mathrm{C}$ ) and accumulated solar radiation (ASR, in MJ.m ${ }^{-2}$ ), of sudangrass cultivars (—) CG Farrapo (....) in four sowing seasons.

Season 1 (December 20, 2016)
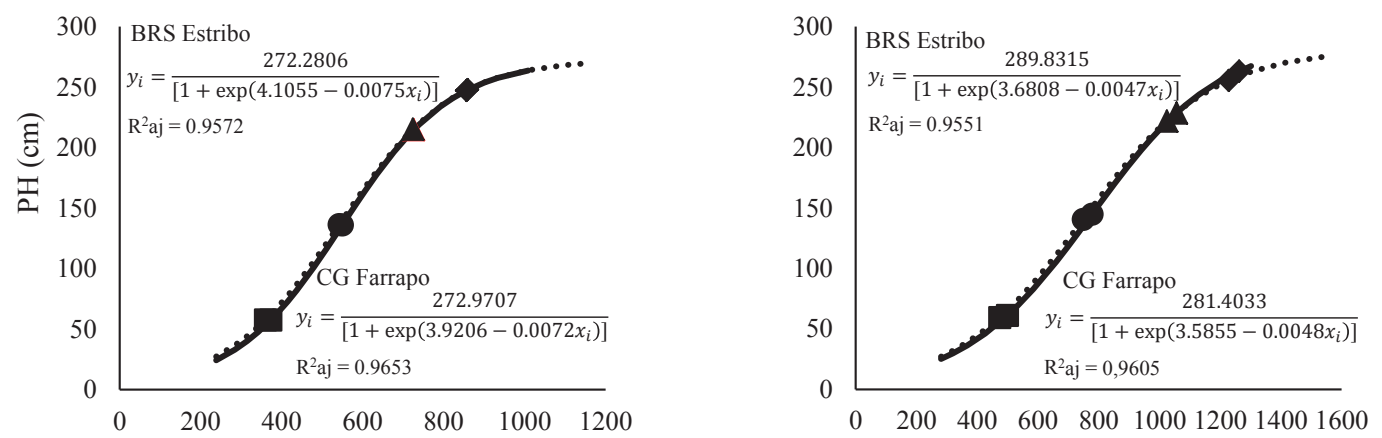

Season 2 (January 20, 2017)
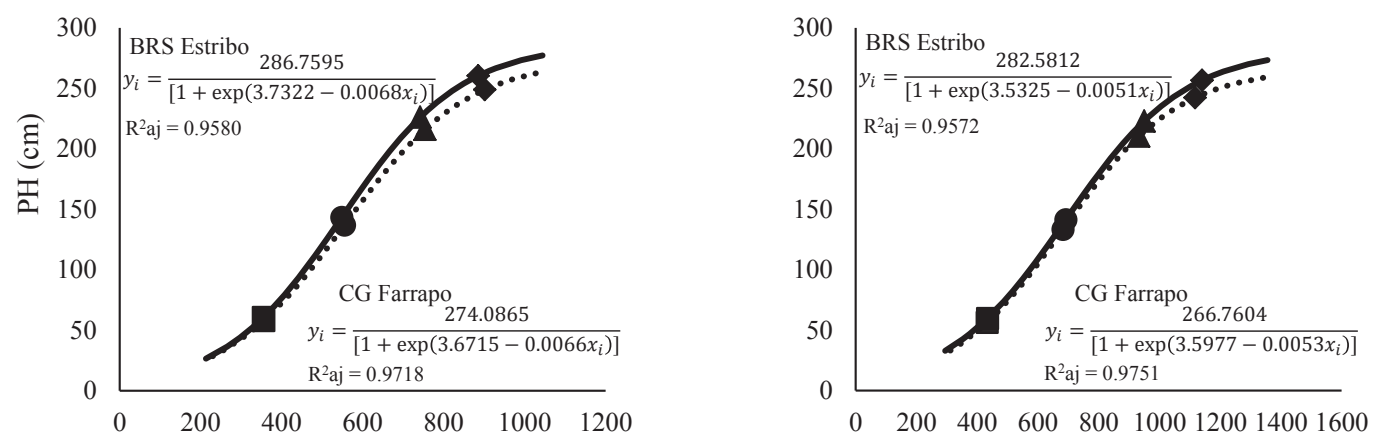

Season 3 (February 7, 2017)
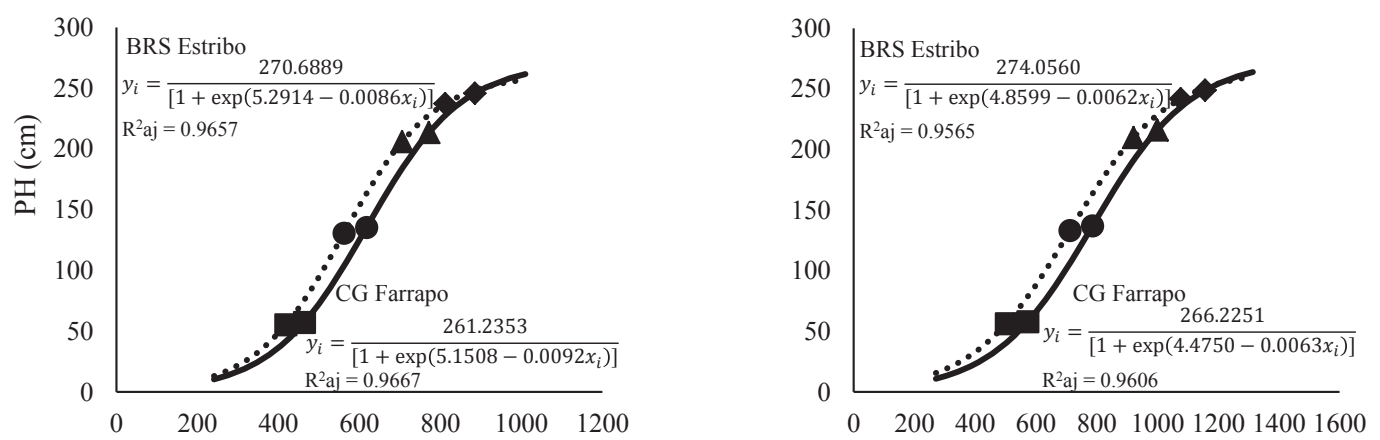

Season 4 (February 24, 2017)
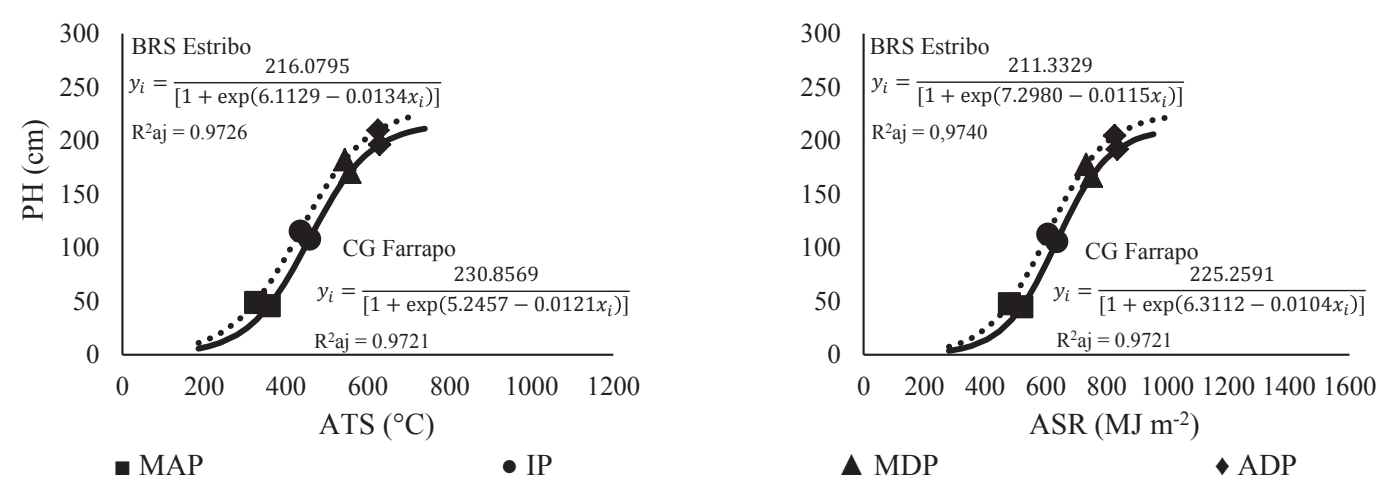
Figure 3. Graphs of the Logistic models for the stem length (SL, in $\mathrm{cm}$ ) as a function of accumulated thermal sum (ATS, in ${ }^{\circ} \mathrm{C}$ ) and accumulated solar radiation (ASR, in MJ.m ${ }^{-2}$ ), of sudangrass cultivars (-) CG Farrapo (.....) in four sowing seasons.

Season 1 (December 20, 2016)
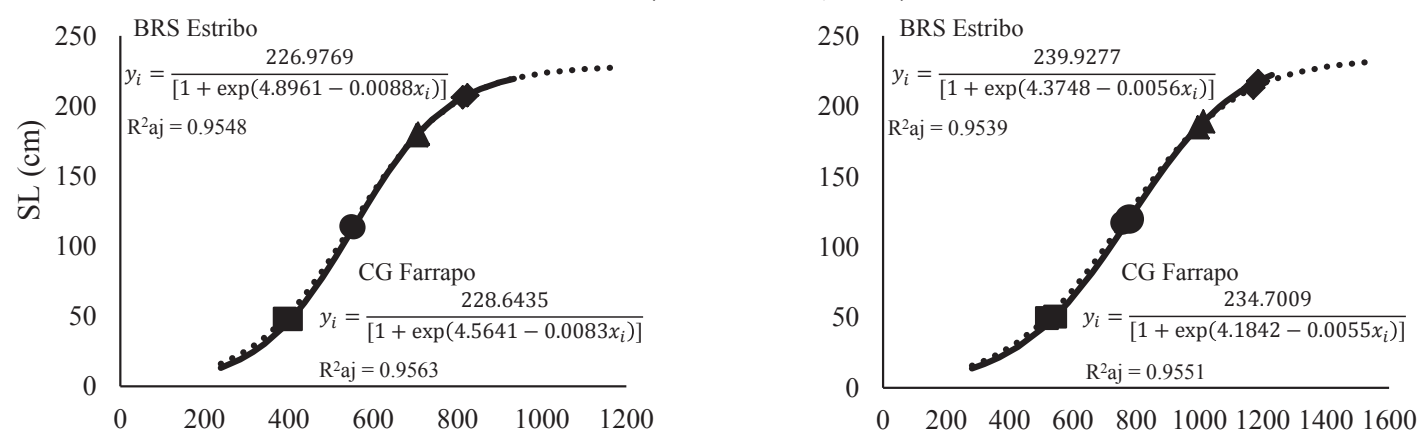

Season 2 (January 20, 2017)
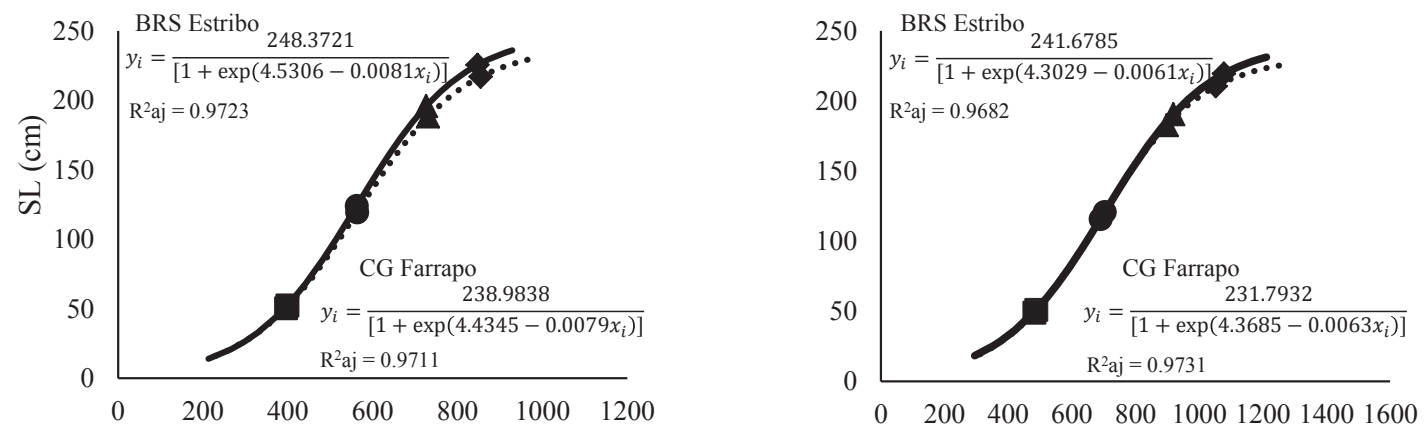

Season 3 (February 7, 2017)
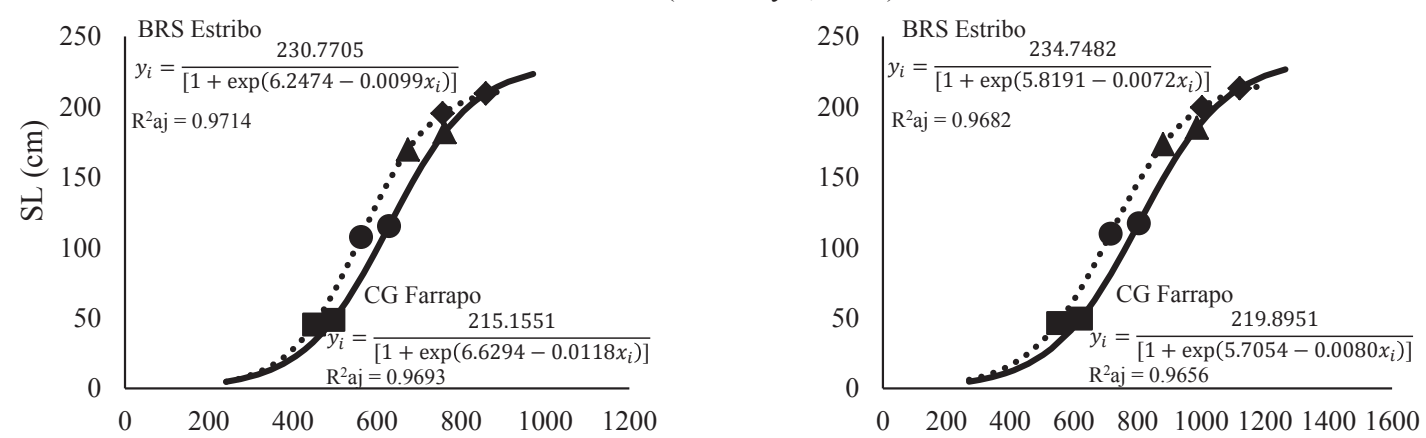

Season 4 (February 24, 2017)
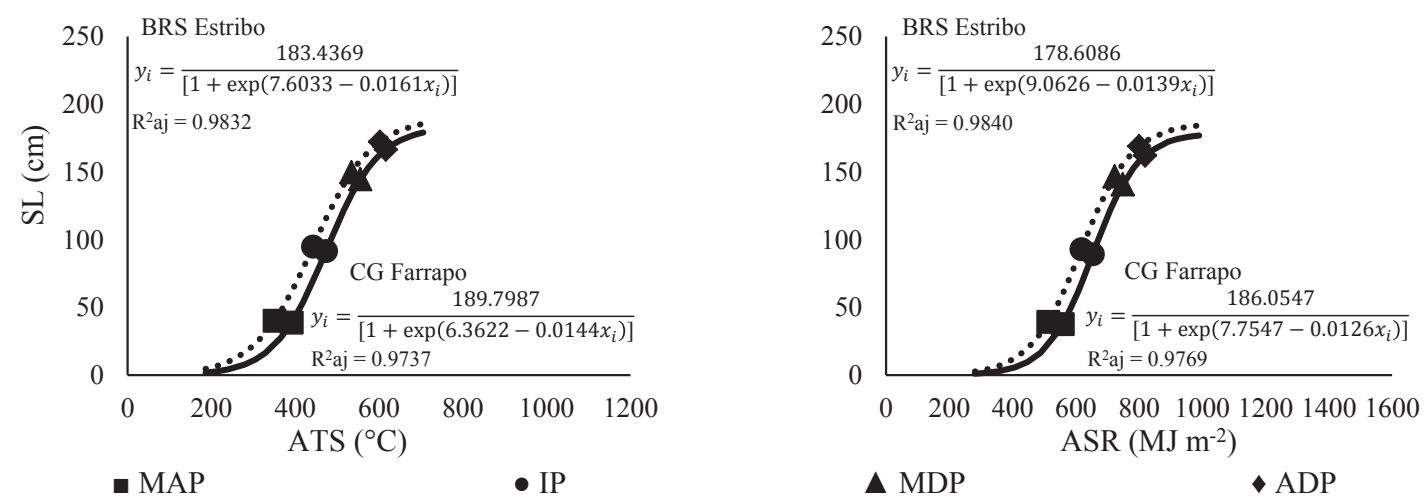

$\triangle \mathrm{MDP} \quad$ ADP 
Among sowing seasons, was verified that the fourth season (February 24 $4^{\text {th }}, 2017$ ), sown at the end of the sowing season indicated for the crop, showed the lowest values for PH and SL and demanded less ATS and ASR to reach all critical points of the growth curve (MAP, IP, MDP, and ADP). Therefore, we can affirm that the delay in the sowing period, exposing the plants to lower temperatures and incident global solar radiation, reduces the crop cycle, decreasing the period between MAP and IP, as well as the period from the IP to the MDP and ADP, when there is a marked decrease in the growth rate and the beginning of the growth stabilization, respectively. Because of the reduction of the crop cycle, the plants presented lower PH and SL.

Based on the results obtained in this work, it is possible to affirm that there is a difference between cultivars within sowing seasons and between sowing seasons of the same cultivar. Thus, we indicate using the model best fitted for a specific cultivar within the sowing season. It is worth noting that the models were adjusted using local meteorological data and for the four sowing seasons. Therefore, the use of the models with meteorological data of another location or sowing season can generate divergent, but expected results. However, since we found no modeling work using the growth of sudangrass and, especially, because of the representativeness of this database (three weekly evaluations of five plants during the crop cycle, in two cultivars sown in four seasons), these models become a reference for future research.

\section{Conclusions}

The accumulated thermal sum and accumulated solar radiation are suitable for use as an independent variable to adjust the Gompertz and Logistic models.

There was a difference between the cultivars at sowing seasons and between sowing seasons for the same cultivar regarding plant height and stem length for both models.
The Gompertz and Logistic models fitted to plant height and stem length of cultivars BRS Estribo and CG Farrapo in four sowing seasons satisfactorily describe the growth behavior. We indicate the Logistic model since it presents better quality indicators.

\section{Acknowledgements}

We thank the Brazilian National Council for Scientific and Technological Development (CNPq - Process 401045/2016-1 e 304652/2017-2), the Coordination for the Improvement of Higher Education Personnel (CAPES), and the Foundation for Research Support of the State of Rio Grande do Sul (FAPERGS), for grants awarded.

\section{References}

ALVARES, C. A.; STAPE, J. L.; SENTELHAS, P. C.; GONÇALVES, J. L. M.; SPAROVEK, G. Köppen's climate classification map for Brazil. Meteorologische Zeitschrift, Berlim, v. 22, n. 6, p. 711-728, 2013. DOI: 10.1127/0941-2948/2013/0507

ARCHONTOULIS, S. V.; MIGUEZ, F. E. Nonlinear regression models and applications in agricultural research. Agronomy Journal, Madison, v. 107, n. 2, p. 786798, 2015. DOI: 10.2134/agronj2012.0506

ARNOLD, C. Y. Maximum-minimum temperature as a basis for computing heats units. Proceedings of the American Society for Horticultural Science, Madison, v. 76, n. 1, p. 682-692, 1960.

AUGOSTINHO, L. M. D.; PRADO, R. M.; ROZANE, D. E.; FREITAS, N. Acúmulo de massa seca e marcha de absorção de nutrientes em mudas de goiabeira Pedro Sato. Bragantia, Campinas, v. 67, n. 3, p. 577-585, 2008. DOI: 10.1590/S0006-87052008000300004

BANDEIRA, A. H.; MEDEIROS, S. L. P.; EMYGDIO, B. M.; BIONDO, J. C.; SILVA, N. G.; LEAL, L. T. Temperatura base inferior e exigência térmica de genótipos de sorgo sacarino. Revista Brasileira de Milho e Sorgo, Sete Lagoas, v. 15, n. 2, p. 240-250, 2016. DOI: 10.18512/1980-6477/rbms.v15n2p240-250

BATES, D. M.; WATTS, D. G. Nonlinear regression analysis and its applications. New York: John Wiley \& Sons, $1988.384 \mathrm{p}$. 
BEM, C. M.; CARGNELUTTI FILHO, A.; FACCO, G.; SCHABARUM, D. E.; SILVEIRA, D. L.; SIMÕES, F. M.; ULIANA, D. B. Growth models for morphological traits of sunn hemp. Semina: Ciências Agrárias, Londrina, v. 38, n. 5, p. 2933-2944, 2017. DOI: 10.5433/1679-0359.2017v3 8n5p2933

BENINCASA, M. M. P. Análise de crescimento de plantas: noções básicas. 2. ed. Jaboticabal: FUNEP, 2003. $41 \mathrm{p}$.

BRITO, C. C. R.; SILVA, J. A. A.; FERREIRA, R. L. C.; SANTOS, E. S.; FERRAZ, I. Modelos de crescimento resultantes da combinação e variações dos modelos de Chapman-Richards e Silva-Bailey aplicados em Leucaena leucocephala (Lam.) De Wit. Ciência Florestal, Santa Maria, v. 17, n. 2, p. 175-185, 2007. DOI: $10.5902 / 198050981949$

FERNANDES, T. J.; PEREIRA, A. A.; MUNIZ, J. A.; SAVIAN, T. V. Seleção de modelos não lineares para a descrição das curvas de crescimento do fruto do cafeeiro. Coffee Science, Lavras, v. 9, n. 2, p. 207-215, 2014. DOI: 10.25186/cs.v9i2.618

GOMES, A. C. S.; ROBAINA, A. D.; PEITER, M. X.; SOARES, F. C.; PARIZI, A. R. C. Modelo para estimativa da produtividade para a cultura da soja. Ciência Rural, Santa Maria, v. 44, n. 1, p. 43-49, 2014. DOI: 10.1590/ S0103-84782013005000145

LEE, J. H.; GOUDRIAAN, J.; CHALLA, H. Using the expolinear growth equation for modelling crop growth in year round cut Chrysanthemum. Annals of Botany, Londres, v. 92, n. 5, p. 697-708, 2003. DOI: 10.1093/aob/ $\operatorname{mcg} 195$

MAIA, E.; SIQUEIRA, D. L.; SILVA, F. F.; PETERNELLI, L. A.; SALOMÃO, L. C. C. Método de comparação de modelos de regressão não-lineares em bananeiras. Ciência Rural, Santa Maria, v. 39, n. 5, p. 1380-1386, 2009. DOI: $10.1590 / \mathrm{S} 0103-84782009000500012$

MARTINS FILHO, S.; SILVA, F. F.; CARNEIRO, A. P. S.; MUNIZ, J. A. Abordagem Bayesiana das curvas de crescimento de duas cultivares de feijoeiro. Ciência Rural, Santa Maria, v. 38, n. 6, p. 1516-1521, 2008. DOI: $10.1590 / \mathrm{S} 0103-84782008000600004$
MELGES, E.; LOPES, N. F.; OLIVA, M. A. Crescimento e conversão da energia solar em soja cultivada sob quatro níveis de radiação solar. Pesquisa Agropecuária Brasileira, Brasília, v. 24, n. 9, p. 1065-1072, 1989.

MISCHAN, M. M.; PINHO, S. Z. Modelos não lineares: funções assintóticas de crescimento. São Paulo: Cultura Acadêmica, 2014. 184 p.

MOZAMBANI, A. E.; BICUDO, S. J. Efeito da temperatura e da luz no desenvolvimento de plântulas de milho. Nucleus, Ituverava, v. 6, n. 1, p. 211-222, 2009. DOI: $10.3738 / 1982.2278 .138$

MUIANGA, C. A.; MUNIZ, J. A.; NASCIMENTO, M. S.; FERNANDES, T. J.; SAVIAN, T. V. Descrição da curva de crescimento de frutos do cajueiro por modelos não lineares. Revista Brasileira de Fruticultura, Jaboticabal, v. 38, n. 1, p. 22-32, 2016. DOI: 10.1590/0100-2945-295/14

OLIVEIRA, A. S.; RIBEIRO, A.; SILVA, C. R. A.; XAVIER, A.; FREITAS, A. F. Modeling the growth of eucalyptus plants based on the thermal sum. Revista Árvore, Viçosa, MG, v. 41, n. 2, p. 1-10, 2017. DOI: 10.1590/1806-90882017000200012

R DEVELOPMENT CORE TEAM - R: a language and environment for statistical computing. Vienna: $\mathrm{R}$ Foundation for Statistical Computing, 2018.

SANTOS, H. G.; JACOMINE, P. K. T.; ANJOS, L. H. C.; OLIVEIRA, V. A.; LUMBRERAS, J. F.; COELHO, M. R.; ALMEIDA, J. A.; CUNHA, T. J. F.; OLIVEIRA, J. B. Sistema brasileiro de classificação de solos. 3. ed. Brasília: EMBRAPA, 2013. 353 p.

SATTELL, R.; DICK, R.; INGHAM, R.; KAROW, R.; McGRATH, D. Sudangrass and sorghum-sudangrass hybrids (Sorghum bicolor L.). Corvallis: EM 8703, Oregon State University extension service, 1998. 2 p.

SILVEIRA, M. C. T.; SANTANNA, D. M.; MONTARDO, D. P.; TRENTIN, G. Aspectos relativos à implantação $e$ manejo de Capim-Sudão BRS Estribo. Bagé: EMBRAPA Pecuária Sul, 2015. 11 p. 
